\title{
いもち病菌の胞子形成玄米率及び被害度が異なる イネ種子に対する消毒効果
}

\author{
内橋嘉一・神頭武嗣・前川和正 \\ （兵庫県立農林水産技術総合センター）
}

\begin{abstract}
Summary
Here, we investigated the effect of disinfection on seeds infected and damaged by Pyricularia oryzae parasitizing rice husk. In all the cases, seed disinfection was highly efficient in controlling the parasitic infection of the surface of rice seeds. Paticularly, application of a solution of benomyl, known for its fungicidal properties, had high efficacy in controlling this pathogen; however,sterol demethylation inhibitors had low efficacy. Further, the effect of disinfection on heavily damaged seeds showing later stages of infection was low.
\end{abstract}

イネいもち病の主要な一次伝染源は, 同病原菌 (Pyricularia oryzae) 罹病種子による苗いもちの本田持ち 込みと考えられているため（原澤, 2001）, イネいもち 病の効率的・効果的な防除を行うためには, 種子消毒の 段階でその伝染環を断つ必要がある。

一方, 玄米に感染したいもち病菌が伝染源として重要 な役割を果たすことも明らかになっている(鈴木・藤田, 1981 ; 早坂ら，2002)。しかし，玄米に高度に感染した 種子に対する消毒効果の知見は充分でない。本稿では, 胞子形成玄米率が異なる種子に対する種子消毒の効果お よび被害度の影響を検討したので報告する。

\section{材料及び方法 \\ 1. 種子消毒剂及び温湯消毒の処理方法}

試験は2013年に, 兵庫県内の 2 産地から採種したいも ち病菌に罹病したと考えられる種子（サンプル A, Bい ずれも品種はヒノヒカリ）を用いて実施した。

供試薬剤はステロール脱メチル化阻害（DMI）剂とし て, ペフラゾエート乳剂 (以下, $\mathrm{P}$ 剂), イプコナゾール・ 銅水和剂 (以下, I剂), 及びフルジオキソニル・ペフ ラゾエート・銅水和剤（以下， F 剂）と, ベンズイミダ ゾール系薬剤のベノミル水和剤（以下, Be 剂）とした。

水選した前述の 2 種の罹病種子を供試し, 薬剤による 種子消毒は, 種子消毒剂 4 剂の24時間種子浸漬を行い,
温湯消毒処理は $60^{\circ} \mathrm{C}$ の温湯による 10 分間の処理を行っ た。種子浸漬の薬液比は $1: 6$, 薬液の水温は $15^{\circ} \mathrm{C}$ とし た。育苗試験に供した種子も同じ処理で行った。それぞ れの実験で用いた種子量は後述した。

\section{2. 籾及び玄米の胞子形成率調査方法}

籾は浸漬後直ちに，玄米は浸漬後 4 日間室内 $\left(25^{\circ} \mathrm{C}\right)$ で乾燥させたものを脱ぷして胞子形成率を以下のように 調査した。すなわち，供試サンプルの籾及び玄米各区 300 粒を50粒ずつろ紙を敷いた直径 $9 \mathrm{~cm}$ のガラスシャー レ上に並べ，ブロッター法（君島，1999）に基づき $25^{\circ} \mathrm{C}$ で胞子形成させた。籾は 3 日後に, 玄米は 2 日後 に実体顕微鏡及び生物顕微鏡により検鏡し, シャーレご とに胞子形成がみられた籾の割合（以下, 胞子形成籾率） 及び玄米の割合（以下，胞子形成玄米率）をそれぞれ 6 反復調査した（第 1 図，第 2 図）。

\section{3. 育苗方法}

育苗試験は次の手順で行った。まず，前述の各種子消

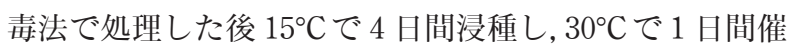
芽した後に長方形プラスチック製容器 $(11.0 \mathrm{~cm} \times 17.5 \mathrm{~cm} \times$ $5 \mathrm{~cm}$ )に $2 \mathrm{~cm}$ の厚さで宇部培土 2 号 (育苗箱 1 枚分 $3 \mathrm{~kg}$ あたり $\mathrm{N}: 0.8 \mathrm{~g}, \mathrm{P}: 0.8 \mathrm{~g}, \mathrm{~K}: 0.8 \mathrm{~g}$ ) をいれ, 乾燥種 子換算で育苗箱 1 枚あたり $120 \mathrm{~g}$ 相当で $14.3 \mathrm{~g}$ をは種し, 宇部培土 2 号で種子が隠れる程度 $(3 \mathrm{~mm})$ 覆土した。

次に, 湿室条件とした人工気象器内で, は種後 $29^{\circ} \mathrm{C}$ で 2 日間出芽処理を行った後，明期 13 時間，夜温 $20^{\circ} \mathrm{C}$, 昼温 $20 \sim 30^{\circ} \mathrm{C}$ で管理した。試験は 3 反復行った。

4. 苗いもち調査方法

は種31日後に鞘葉，第 1 葉 (不完全葉), 第 2 葉に 病斑を形成した苗を苗いもちとして調査した（伊藤, 1943)。

\section{5。玄米被害度の調査方法}

脱ぷした後の玄米 100 粒について，50粒ずつろ紙を敷 いたガラスシャーレ上に並べ，ブロッター法に基づき

Kaichi Uchihashi, Takeshi Kanto and Kazumasa Maekawa (Hyogo Pref. Tech. Cent. for Agric. Forest. and Fish.): Effect of disinfection on seeds infected and damaged by Pyricularia oryzae parasitizing rice husk 2015年 2 月17日受理 


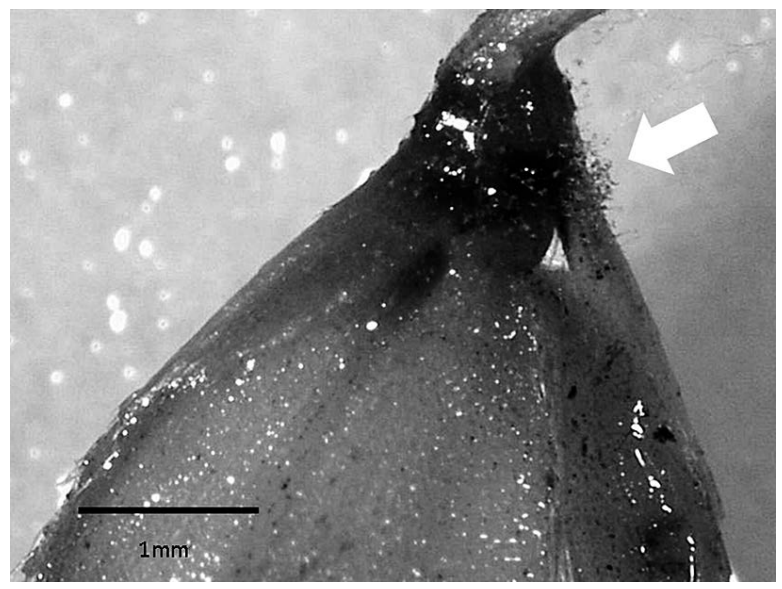

第 1 図 無処理区の籾の護穎に形成されたいもち病菌分生子

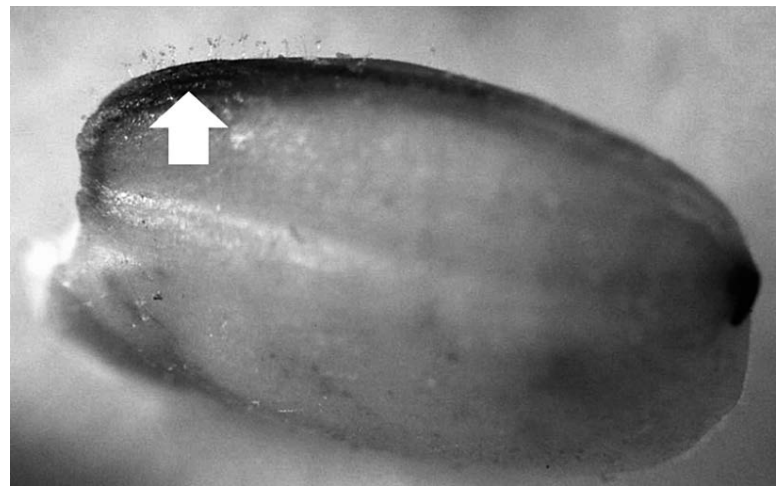

第2図 無処理区の玄米の背縦溝部分に形成されたいもち病菌 分生子 $25^{\circ} \mathrm{C}$ で培養し, 2 日後に玄米表面の胞子形成面積に応 じて次の基準により被害度を調査した。反復は行わな かった。

$\mathrm{a}$ : 玄米背面の背縦溝の $3 / 4$ 以上に胞子形成した玄米数, b : 同 $1 / 2$ 以上 $3 / 4$ 未満に胞子形成, $c$ : 同 $1 / 4$ 以上 $1 / 2$ 未満 に胞子形成, $\mathrm{d}$ : 同 $1 / 4$ 以下に胞子形成, $\mathrm{e}$ : 胞子形成なし。 被害度 $=(4 \times a+3 \times b+2 \times c+1 \times d) /(4 \times$ 調查玄米数 $) \times 100$

\section{結果および考察}

1. 供試サンプルのいもち病胞子形成籾率及び玄米率 薬棛による種子消毒及び温湯消毒の籾や玄米に感染し たいもち病菌および苗いもちへの防除効果を第 1 表に示 した。サンプル A の胞子形成籾率は21.0\%，B は21.7\% で同程度であったのに対して, 胞子形成玄米率はサンプ ル A が7.0\%, B は3.3\%と2.1倍となり, サンプル A はよ り高率でいもち病菌が玄米に感染した種子であることが 判明した。

2. 種子消毒剤及び温湯消毒の罹病種子及び苗いもち等 への防除効果

籾表面に感染したいもち病菌に対しては, いずれの消 毒法でも両サンプルに対して胞子形成は認められず，高 い効果があった。このことから, 今回供試した薬剤及び 温湯消毒はいずれも籾表面に感染したいもち病菌に対し て高い殺菌効果を有すると考えられる。

一方，玄米に感染したいもち病菌に対しては，Be 剂 を除くすべての剂の効果が低く, 特にサンプル A で処

第 1 表 種子消毒剂及び温湯消毒の苗いもち等への防除効果

\begin{tabular}{|c|c|c|c|c|c|c|c|}
\hline \multirow{3}{*}{ 処理法 } & \multirow{3}{*}{ 供試薬剂・処理程度 } & \multicolumn{3}{|c|}{ サンプル $\mathrm{A}^{\mathrm{a})}$} & \multicolumn{3}{|c|}{ サンプル $\mathrm{B}^{\mathrm{a})}$} \\
\hline & & \multicolumn{2}{|c|}{ 胞子形成率 $(\%)^{\mathrm{b})}$} & 苗いもちc) & \multicolumn{2}{|c|}{ 胞子形成率（\%) } & 苗いもち \\
\hline & & 籾 & 玄米 & 発病株率 $(\%)^{\mathrm{d})}$ & 籾 & 玄米 & 発病株率（\%) \\
\hline \multirow[t]{4}{*}{ 24時間浸漬 } & $\mathrm{P}$ 剂 ${ }^{\mathrm{e}}$ & $0 \mathrm{a}^{\mathrm{f})}$ & $3.3 \mathrm{~b}$ & $1.9 \mathrm{a}$ & $0 \mathrm{a}$ & $1.3 \mathrm{~b}$ & $1.0 \mathrm{a}$ \\
\hline & I 剂 & $0 \mathrm{a}$ & $3.7 b^{* * 8)}$ & $2.4 a^{*}$ & $0 \mathrm{a}$ & $0.3 \mathrm{a}$ & $1.3 \mathrm{a}$ \\
\hline & $\mathrm{F}$ 剂 & $0 \mathrm{a}$ & $2.0 \mathrm{a}$ & $1.2 \mathrm{a}$ & $0 \mathrm{a}$ & $2.0 \mathrm{~b}$ & $0.4 \mathrm{a}$ \\
\hline & $\mathrm{Be}$ 剂 & $0 \mathrm{a}$ & $0 \mathrm{a}$ & $1.2 \mathrm{a}^{*}$ & $0 \mathrm{a}$ & $0 \mathrm{a}$ & $0.5 \mathrm{a}$ \\
\hline \multirow[t]{2}{*}{ 温湯浸漬 } & $60^{\circ} \mathrm{C} 10$ 分間 & $0 \mathrm{a}$ & $0.7 \mathrm{a}$ & $2.8 \mathrm{a}$ & $0 \mathrm{a}$ & $0.7 \mathrm{a}$ & $1.0 \mathrm{a}$ \\
\hline & 無処理 & $21.0 \mathrm{~b}$ & $7.0 \mathrm{~b}^{*}$ & $6.5 \mathrm{~b}$ & $21.7 \mathrm{~b}$ & $3.3 \mathrm{~b}$ & $7.7 \mathrm{~b}$ \\
\hline
\end{tabular}

a) 供試種子 : 2013年産罹病種子（品種 : ヒノヒカリ）を用いた。

b) ブロッター法により，各区 50 粒の 6 反復を調査した。

c) 育苗方法 : $11.0 \mathrm{~cm} \times 17.5 \mathrm{~cm}$ のプラスチックトレイに $14.3 \mathrm{~g}$ を播種し，グロースチャンバー内で 1 区あたり 3 反復を育苗，播種 31 日 後に調査した。

d) 発病株率 : 鞘葉, 第 1 葉 (不完全葉) 及び第 2 葉に病斑を形成した苗の割合を示す。

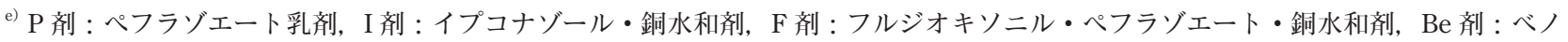
ミル水和剂

f) 同列内の異なる英文字を付した数值間には有意差があることを示す（Tukey 法による多重比較検定， P $<0.05 ）$

g) 同行内の同じ調査項目間に有意差があることを示す（ $\mathrm{t}$ 検定，* : $\mathrm{P}<0.05 ， * *: \mathrm{P}<0.01$, 数值が高い方にのみ付した） 


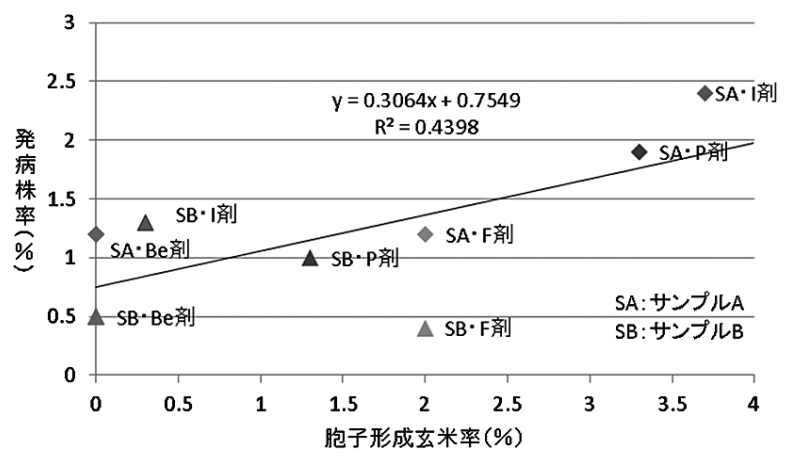

第 3 図薬剤処理区の胞子形成玄米率が苗いもちの発病株率に 及ばす影響

理後の胞子形成玄米率はそれぞれ，P 剂3.3\%，I剂3.7\% 及び $\mathrm{F}$ 剂 $2.0 \%$ と高く, 特に I 剂でサンプル B の $0.3 \%$ と 大きな効果の差が見られた。温湯消毒はサンプル A で 0.7\%，B で $0.7 \%$ と比較的高い効果が得られた。

他方, Be 剂はサンプル A, B ともに処理後の胞子形 成玄米率が $0 \%$ となり，玄米に感染したいもち病菌に高 い殺菌効果を示した。これは，Be 剂が籾殼組織を経て 玄米にまで到達する浸透移行性において優れているため と考えられる（木村・小川，2005）。

苗いもちの発病株率をみると，無処理を除く全ての処 理区でサンプル A の苗いもち発生率が B のそれを上回っ た。また，薬剤処理区の胞子形成玄米率と発病株率との 関係を第 3 図に示す。両者の間に $\mathrm{R}^{2}=0.44$ と正の相関が 認められた。

早坂ら（2002）は，玄米に感染したいもち病菌に対し てステロール脱メチル化阻害（DMI）剤の防除効果が劣 るため，苗いもちが発生することを報告している。本試 験に打いても，胞子形成玄米率が7.0\%とサンプル B の 3.3\%を上回るサンプル A の種子消毒効果がより得られ ないのは DMI 剤の玄米に感染したいもち病菌に対する 効果が十分でないためと考えられる。

サンプル A， B とも Be 剂及び温湯消毒で胞子形成玄 米率よりも苗いもち発病株率が高い場合があった。これ は籾殼の組織内部や内側表面に感染したいもち病菌が発 病に影響した可能性がある。

また，薬剤によっては胞子形成玄米率が高くても苗い もちの発病株率が低くなるものがあった。この原因は, 浸種の際, 催芽に伴って籾殼が動き, 玄米に感染したい もち病菌に薬剤の影響があった可能性がある。

あるいは，薬剤によっては播種後育苗時に防除効果を 発現していることが考えられる。今後，浸種から育苗ま での各ステージにおける各薬剤の作用機作の解明が必要 であると考えられる。

\section{3. 玄米被害度調查結果}

サンプル A，B の玄米被害度を第 2 表に, 被害程度別 粒数を第 4 図に示した。それぞれの被害度は，9.5（サ ンプル A）と2.8（サンプル B）と算定された。

今回設定した調査基準により，被害程度別に分別する ことができた。玄米に寄生したいもち病菌が苗いもちの 原因の 1 つであり，その被害度が種子消毒の防除効果に 影響を及ぼしていると推察されるため, 今後, 例数を増

第 2 表 玄米被害度の比較

\begin{tabular}{lc}
\hline & 玄米被害度 $^{\mathrm{a})}$ \\
\hline サンプル $\mathrm{A}$ & 9.5 \\
サンプル $\mathrm{B}$ & 2.8 \\
\hline $\mathrm{A} / \mathrm{B}^{\mathrm{b})}$ & 3.4 \\
\hline
\end{tabular}

a) 各サンプルの玄米 100 粒をブロッター法により, 玄米の背面 の背縱溝の胞子形成を調査し，次式に基づき被害度を算出した a 玄米背面の背縱溝の $3 / 4$ 以上に胞子形成, b 同 $1 / 2$ 以上 $3 / 4$ 未 満, c 同 $1 / 4$ 以上 $1 / 2$ 未満, d 同 $1 / 4$ 未満, e 胞子形成なし 被害度 $=(4 \times \mathrm{a}+3 \times \mathrm{b}+2 \times \mathrm{c}+1 \times \mathrm{d}) /(4 \times$ 調査玄米数 $) \times 100$ b) サンプル A の玄米被害度を $\mathrm{B}$ のそれで除した比率
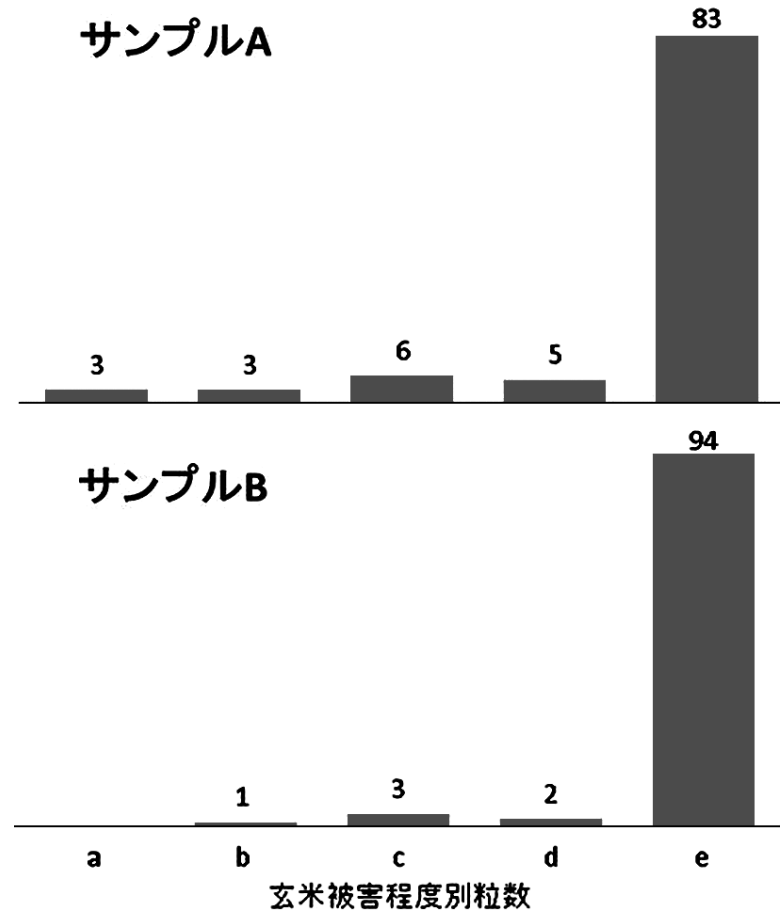

第4図 玄米被害程度別粒数

玄米被害程度 : 各サンプルの玄米100粒をブロッター 法に基づき, 玄米の背面の背縱溝の胞子形成を調査し, 次の基準に基づき被害程度を算出した

a 玄米背面の背縱溝の $3 / 4$ 以上に胞子形成, b 同 $1 / 2$ 以上 $3 / 4$ 未満, c 同 $1 / 4$ 以上 $1 / 2$ 未満, d 同 $1 / 4$ 未満, e 胞子形成なし 
やし，玄米被害度と発病株率との関係を検証する必要が ある。

以上の結果より, 今回供試した種子消毒剂 4 剂及び温 湯消毒は籾に感染したいもち病菌に対して高い消毒効果 を有し, 特にBe 剂は玄米に感染したいもち病菌への消 毒効果も優れていることが明らかになった。

今後, いもち病感染籾の評価として, 籾及び玄米の胞 子形成率だけではなく，被害度を加えることを検討する 必要がある。

\section{引用文献}

原澤良栄（2001）日植病報 $67: 87-96$.

早坂 剛ら（2002）日植病報 $68: 297-304$.

伊藤誠哉（1943）稲いもち病.養賢堂，東京，pp. 10 .

君島悦夫（1999）種子伝染病の生態と防除. 日本植物防疫協会, 東京, pp. 101-102.

木村教男・小川正臣（2005）日植病報 $71: 111-118$.

鈴木穂積・藤田佳克（1981）北日本病虫研報 $32:$ 98-99. 